УДК 656.2.001.47

Сазонова Т.О., к.е.н., доцент,

доцент кафедри менеджменту ім. І. А. Маркіної

Sazonova T. Candidate of Economic Sciences, Associate Professor https://orcid.org/0000-0003-1454-5135

Потапюк І.П., к.е.н., доцент, доцент кафедри менеджменту ім. I. А. Маркіної

Potapiuk I. Candidate of Economic Sciences, Associate Professor

https://orcid.org/0000-0002-1051-0114

Януш В.А., здобувач вищої освіти

Janush V., student

\title{
ОСОБЛИВОСТІ КОРПОРАТИВНОЇ КУЛЬТУРИ ОРГАНІЗАЦІЇ В СУЧАСНИХ РЕАЛІЯХ
}

\author{
Полтавський державний аграрний університет
}

В статті розглянуто сутність корпоративної культури, особливості ії функціонування в умовах сучасного бізнес-середовища. Визначена роль корпоративної культури у системі менеджменту організації. Охарактеризований управлінський та соціально-психологічний вплив корпоративної культури на організацію в цілому та персонал зокрема. Зроблена спроба довести вплив корпоративної культури на всі організаційні процеси: виробництва, трудові, технології, маркетингу, комунікаційні, процеси кар'єри та соціалізації, а також прийняття та ухвалення рішень; на організаційну поведінку (індивіда та колективу, мотивацію та соціально-психологічний клімат); на конкурентоспроможність, потенціал організації.

Враховуючи групування організаційних цінностей за визначеними ознаками: на етико-соціальні, економіко-прагматичні та емоційно-розвивальні, запропоновані варіанти їх доповнення, продиктовані вимогами сучасності та всесвітньою пандемією COVID-19. Це цінності життя, безпеки, єдності, самодисципліни та взаємодопомоги, залучення. Запропоновані заходи із модернізації корпоративної культури в сучасних нестабільних умовах, з огляду на виклики зовнішнього середовища, які охоплюють індивідуальну діагностику впливу пандемії на організацію, розробку схему заходів переміщення та захисту персоналу, організацію роботи у нових реаліях, забезпечення персоналу необхідними технологіями, а також розробку нових підходів до управління згуртованістю та лояльністю персоналу. Сформовані поради для менеджерів щодо управління в умовах гібридної трудової діяльності (змішаний тип online та offline). Сформований вектор розвитку корпоративної культурі з акцентом на забезпечення бізнес-безпеки, кадрової безпеки, що передбачає, культивування оновлених цінностей, норм, правил; залучення персоналу; впровадження системи підтримки працівників; впровадження інновацій в робоче середовище тощо.

Ключові слова: корпоративна культура, організаџія, персонал, цүінності, соиіально-орієнтований підхід, потенціал, безпека організації, бізнес-середовище, синергія.

\section{ОСОБЛИВОСТІ КОРПОРАТИВНОЇ КУЛЬТУРИ ОРГАНІЗАЦІЇ В СУЧАСНИХ РЕАЛІЯХ}

\section{Полтавський державний аграрний університет}

The article considers the essence of corporate culture, features of its functioning in the modern business environment. The role of corporate culture in the organization's management system was determined. The managerial and socio-psychological influence of corporate culture on the organization in general, and its staff in particular, was characterized. An attempt is made to prove the influence of corporate culture on all organizational processes. There are production, labor, technology, marketing, communication, career and socialization processes, decision-making; organizational behavior (individual and team, motivation and socio-psychological climate); competitiveness, potential of the organization.

Considering the grouping of organizational values according to certain characteristics: ethical-social, economic-pragmatic and emotional-developmental, the proposed options for their supplementation, dictated by modern requirements and the global pandemic COVID-19. There are the values of life, security, unity, selfdiscipline and mutual assistance, involvement. Proposed measures to modernize corporate culture in unstable 
environment, given the challenges of the environment, which include individual diagnosis of the impact of the pandemic on the organization, development of a scheme of relocation and protection of personnel, organization of work in new realities, providing staff with necessary technologies and new approaches to managing staff cohesion and loyalty. Formed advice for managers on management in a hybrid work environment (mixed type online and offline). The vector of development of corporate culture with an emphasis on ensuring business security, personnel security, which provides for the cultivation of updated values, norms, rules; staff involvement; introduction of a support system for employees; introduction of innovations into the work environment, etc.

Keywords: business environment, corporate culture, organization, personnel, potential, security of the organization, socially-oriented approach, synergy, values.

Постановка проблеми у загальному вигляді i ïi зв'язок 3 важливими науковими та практичними завданнями. Ефективність та результативність діяльності сучасної організації визначається низкою формально та неформально регламентованих факторів, правил, норм та настанов. Якщо формалізована складова діяльності організації (техніко-технологічна, організаційна, фінансово-економічна, маркетингова тощо) $\epsilon$ зрозумілою та чітко виваженою, то неформальна, що об'єднує відносини всередині та за межами організації, які, в свою чергу, формуються під впливом історичного досвіду (діяльності самої організації, регіону, держави, галузі тощо), менталітету, звичаїв, традицій, цінностей, наявності неформальних відносин в організації, iї індивідуального соціально-психологічного мікроклімату, $\epsilon$ дещо «розмитою» в більшості сучасних організацій, особливо малого та середнього розміру. Разом з тим, ціннісні орієнтири, сукупність норм як в житті людини, так і організації, визначають напрямок їх функціонування, розвитку та визначають якість їх взаємодії. Сучасне бізнес-середовище характеризується нестабільними, мінливими умовами функціонування, які пов'язані не лише з нестабільністю економічної, політичної та соціальної систем, але й всесвітньою пандемією COVID-19, що впливає на їх розбалансованість зі свого боку. Врахування останнього некерованого фактору має відбуватися в системі менеджменту організацій, що функціонують в сучасному бізнес-середовищі.

Аналіз останніх досліджень, у яких започатковано вирішення проблеми. Поняття та роль корпоративної культури в системі управління організацій будь-яких розмірів, галузевої спрямованості розглядалися багатьма науковцями в різні часи їх досліджень. Очевидним є той факт, що вони не прийшли до єдиного визначення даного явища. Наприклад, корпоративна культура розглядається як система цінностей, вірувань, очікувань, символів, переконань, уявлень, ділових принципів, норм поведінки, традицій тощо, які історично сформувалися в організації (iі підрозділах) та сприймаються більшістю співробітників (М. Семикіна) [1, с. 69-70]; як сфера менеджменту, пов'язана 3 розвитком інтеграційних процесів, що включає цінності (основний компонент) персоналу організації, переконання, норми поведінки, комунікації в процесі трудової діяльності, елементи матеріального середовища, відображаючи індивідуальний образ конкретної організації (Ю. Бугаєвська) [2, с.13]; як сукупність ціннісних установок, норм, формальних, неформальних законів поведінки, які відображають соціальні, економічні, виробничі відносини, що склалися в організації та культивуються, в першу чергу, їі керівництвом (Н. Гриценко) [3, с. 285]; як «дух компанії»: всі співробітники чітко усвідомлюють завдання компанії, керуючись прийнятими в ній нормами та правилами поведінки, міжособистісних комунікацій, прикладають максимальні зусилля для їх реалізації (I. Терон) [4, с. 640]; як специфічний вид та набір норм, цінностей, переконань і манер поведінки, які характеризують способи співпраці колективу, а також окремих осіб в межах конкретної організації та поза ними (Т. Сазонова, I. Потапюк) [5, c. 133].

Разом $з$ тим, вважаємо за необхідність розглянути особливості формування, функціонування та розвитку корпоративної культури, як індивідуального, специфічного утворення, але з врахуванням загального дестабілізуючого фактору впливу. 
Цілі статті. Дослідити особливості формування корпоративної культури в умовах пандемії та сформувати напрями ії удосконалення для сучасних організацій, враховуючи вказаний дестабілізуючий фактор.

Виклад основного матеріалу дослідження 3 повним обгрунтуванням отриманих наукових результатів. Розглянемо корпоративну культуру через призму управлінського та психологічного впливу на персонал та діяльність організації в цілому (рис. 1).

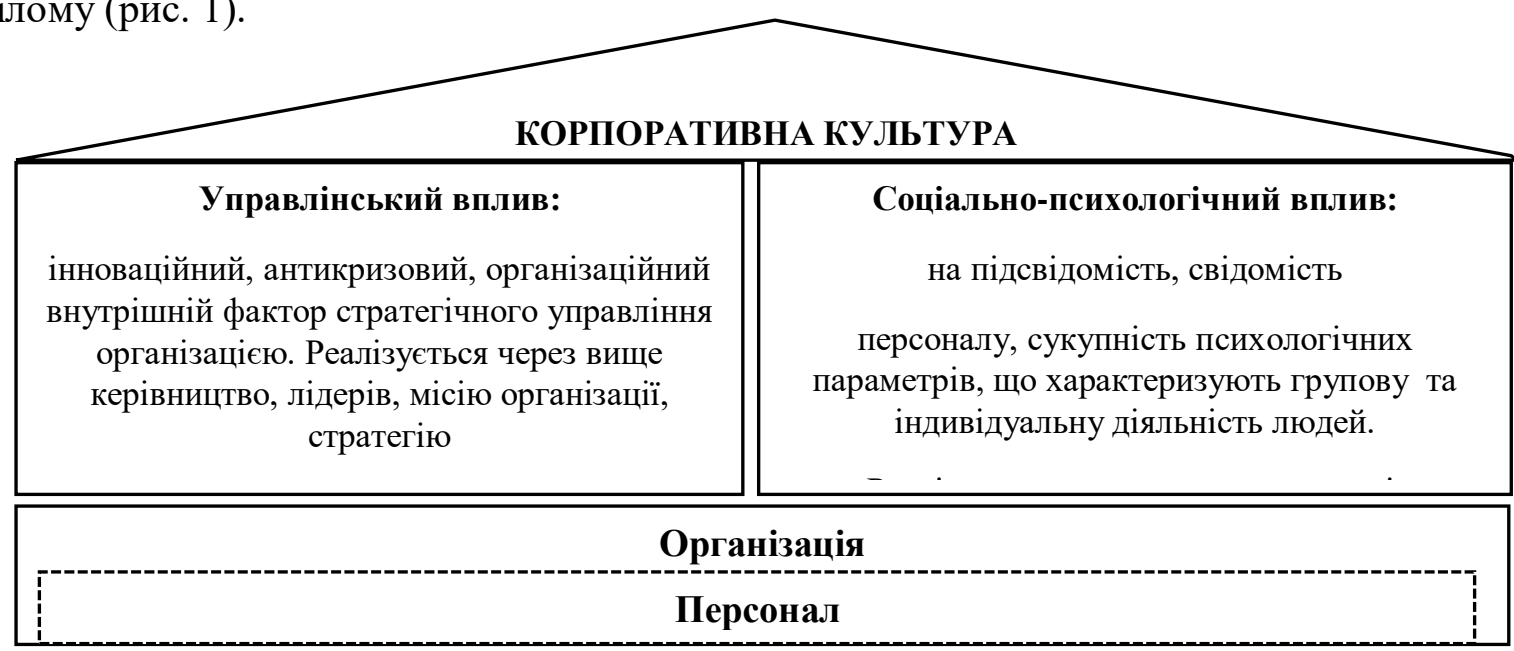

Рис. 1. Модель управлінського та соціально-психологічного впливу корпоративної культури на діяльність організації [власна розробка]

Так, корпоративна культура відіграє роль системоутворюючого фактору в організації. Вона базується та водночас впливає, визначає характер та напрямок управлінського та соціально-психологічного впливів на організацію в цілому, та персонал зокрема. Зважаючи на необхідність пріоритетного застосування соціальноорієнтованого підходу в управлінні та характер впливу корпоративної культури, природним $є$ наступний висновок: формування та розвиток корпоративної культури організації має відбуватися, головним чином, із використанням соціально-орієнтованого підходу. При цьому варто пам'ятати про ефект синергії, який завжди буде спостерігатися при наявності виваженої, репрезентативної сучасним реаліям та індивідуальному образу організації корпоративної культури, а також чіткому стратегічному векторі її розвитку. Корпоративна культура, фактично, діє на діяльність організації у чотирьох напрямах: процеси, організаційна поведінка, конкурентоспроможність та потенціал.

Так, корпоративна культура впливає на виробничий та трудові процеси (якість, інноваційність, відповідність плановим показникам тощо); комунікаційні процеси (всередині та за межами організації, міжгрупові та міжособові, формальні та неформальні комунікації); процеси ухвалення рішень (методи, способи); процеси кар'єри та соціалізації (вид, практика управління, процедурне забезпечення процесу, прозорість та зрозумілість).

Корпоративна культура здійснює прямий вплив на організаційну поведінку: поведінку індивіда та поведінку колективу, групи (правила, форми, норми, традиції спілкування, як офіційного, так і неофіційного), мотивацію персоналу різних категорій, соціально-психологічний клімат в цілому (рівень конфліктності, конфліктологічну грамотність в цілому, рівень лояльності, задоволеності персоналу, статусність тощо).

Вплив корпоративної культури на конкурентоспроможність організації грунтується на двох попередніх. Наслідком ефективної корпоративної культури $\epsilon$ позитивний зовнішній та внутрішній імідж організації, а також позитивна репутація в бізнес-середовищі та соціумі. 
Четвертий напрямок - вплив на потенціал організації, на наш погляд більш правильно охарактеризувати як вплив на сукупність потенціалів: виробничого, ринкового, інноваційного, ресурсного та трудового. Його можна розглядати, як синергетичне ядро впливу, або логічним наслідком впливу.

Сконцентруємо увагу на «серці» корпоративної культури - цінностях. На думку деяких авторів $[6,7,8,9$, с. 40], з якими ми погоджуємося, цінності можна поділити на три рівні:

1) етико-соціальні - лежать в основі індивідуальної та групової поведінки людей, наприклад - повага, чесність, лояльність.

2) економіко-прагматичні - підтримують та об'єднують різні організаційні системи, наприклад - ефективність, результативність, якість, плановість та дисципліна в усьому, головний контроль - самоконтроль.

3) емоційно-розвивальні - створюють нові можливості в діяльності та розвитку організації, персоналу, наприклад - креативність, самопізнання, впевненість, гнучкість, інноваційність.

Отже, роль корпоративної культури в стабілізації діяльності організації та іiі розвитку є основоположною.

В часи всесвітньої пандемії COVID-19 перед топ-менеджментом організацій постало питання не лише як зберегти власний бізнес, ринкові позиції, або стабілізувати ïx, але й, враховуючи соціально-орієнтований підхід в управлінні, - як захистити персонал, причому не лише кількісно, але й якісно. Варто прийняти до уваги, що в сучасних реаліях зазнали змін й управлінські рішення - форми їх прийняття, доведення до виконавців, характер тощо. Ситуація, що склалася як у виробничій, так і соціальній сфері, викликана дією пандемії COVID-19, сформувала нове світосприйняття у персоналу. У світі нестабільності та хаосу, працівники з надією спрямовують погляд на власне керівництво. У персоналу можуть (часто саме це й спостерігається) переважати панічні настрої, пов'язані із страхом захворіти, померти, втратити роботу, втратити звичний рівень доходу тощо. В такому випадку керівник стає орієнтиром та «острівцем» стабільності - його задача - сформувати ефективні комунікаційні канали, забезпечити результативність комунікаційного процесу, незалежно від того чи робота відбувається в офісі чи віддалено. 3 проблемою неефективності комунікаційної системи стикнулися майже всі організації на перших хвилях карантину.

3 метою адекватної трансформації в системі корпоративної культури, необхідно спочатку:

1) оцінити ступінь впливу пандемії на власний персонал та бізнес (настрої, настанови працівників, їх переконання, зрушення в системи бізнес-відносин, бізнеспроцесів тощо);

2) розробити схему заходів переміщення (за потреби) та захисту персоналу;

3) організувати роботу у нових реаліях, забезпечити персонал необхідними технологіями;

4) розробити нові підходи до управління згуртованістю та лояльністю персоналу.

Пропонуємо в ціннісну основу організації покласти життя, безпеку, єдність, самодисципліну та взаємодопомогу, залучення. Наявність поки що нескінченної загрози гібридної взаємодії (on / offline), яка створює загрозу не лише для психологічної складової комунікації, але й для відчуття команди, єднання, залученості тощо. Що ж може зробити керівництво, не змінюючи кардинально корпоративну культуру, але налаштовуючи їі під вимоги сьогодення?

В першу чергу - чітко формулювати власні очікування від працівників. Прозорість у системі вимоги - очікування, слугують для працівника одночасно спрямовуючим та стабілізаційним фактором, що посилює впевненість як окремого працівника, так і колективу (команди) в цілому.

По-друге, частіше надихати персонал та менше давати дрібних доручень, 
неважливих вказівок тощо. Персонал має відчувати не лише позитивний, оптимістичний настрій керівництва (на інший воно просто немає права), але й власну причетність, залучення до справ організації, досягнення іiі цілей. При цьому загальний вектор досягнень не має «розмиватися» другорядними, неважливими, обтяжливими розпорядженнями.

По-трете, стимулювати, мотивувати впровадження інновацій на робочому місці. Зокрема, вони можуть стосуватися робочих умов, графіку тощо. Наприклад, відносно умов праці - це може бути дозвіл обирати де, коли і як працювати (звісно із вказанням всіх контрольних параметрів). Це може допомогти максимально використати кадровий потенціал та можливості персоналу, при цьому створюючи передумови для економії ресурсів.

По-четверте, створити механізми підтримки персоналу. Така підтримка охоплює психологічну, інформаційну, медичну та фінансову складові.

По-п'яте, опрацювати прозорі та зрозумілі протоколи та обов'язки для працівників з групи ризику. В тому числі, опрацювати протоколи захисту працівників, при виявленні в колективі хворого на COVID-19 (дезінфекція робочих місць, переведення працівників, які були у безпосередньому контакті з хворим на самоізоляцію та віддалену роботу тощо).

I, нарешті, шосте - заохочувати неформальне спілкування в колективі. Неформальні комунікації призводять до співробітництва, обміну ідей та укріплення соціальних зв'язків, які $є$ важливими як в стратегічному, так і тактичному розрізах. Керівництво повинне більше планувати, розробляти та впроваджувати нові способи такої взаємодії в умовах роботи як в online-режимі, так і offline-режимі.

Стосовно удосконалення корпоративної культури 3 метою удосконалення, укріплення виробничого, фінансово-економічного потенціалу підприємства в сучасних умовах функціонування бізнес-середовища, то, на наш погляд, вона має орієнтуватися на:

1) формування чітких, зрозумілих для всіх перспектив, які слугуватимуть орієнтирами для індивідуальної програми розвитку, саморозвитку та програми досягнень працівників;

2) єдність колективу, співзалежність та відповідальність його членів;

3) формування єдиної системи організаційних цінностей, норм та правил, які мають постійно культивуватися та переноситися із сфери формального закріплення, у практичну (власний приклад, популяризація, стимулювання, визнання тощо);

4) визначення місця кожного працівника в організаційній структурі та структурі управління, його ролі не просто згідно займаній посаді, а відповідно його схильностям, компетентності, вмінням та досвіду;

5) формування почуття довіри та відданості спільній справі та організації в цілому;

6) залучення до процесу прийняття управлінських рішень та надання можливості позитивно впливати на результати діяльності власної та колективу (через стимулювання, мотивацію до інноваційної поведінки тощо);

7) формування соціально-відповідальної поведінки як в межах організації, так і за iї межами (клієнти, споживачі, органи влади, соціум тощо).

Управління розвитком корпоративної культури на соціально-орієнтованих засадах та на засадах пріоритетності бізнес-складової, по-суті, є односпрямованим. Механізм управління включає заходи спрямовані на забезпечення кадрової безпеки та безпеки діяльності організації в цілому в сучасному бізнес-середовищі, що формує єдину стабілізаційну систему, сформовану для конкретної організації на основі модифікованої корпоративної культури, сукупності потенціалів, у відповідь на зовнішні та внутрішні загрози.

Висновки. Отже, корпоративна культура - складне, комплексне, індуалізоване 
утворення, що формує не лише унікальний образ організації, але й визначає засади іiі функціонування, розвитку, конкурентоспроможності, а іноді й виживання та стабілізації власних позицій. Вона здійснює управлінський та соціально-психологічний вплив на персонал та організацію загалом, зокрема - на всі процеси, організаційну поведінку, конкурентоспроможність та потенціал господарської одиниці. «Серцем» корпоративної культури $є$ цінності (етико-соціальні, економіко-прагматичні та емоційно-розвивальні). В сучасних умовах функціонування, які характеризуються дестабілізуючим впливом всесвітньої пандемії COVID-19 виникає необхідність «утримання» та модернізації існуючої корпоративної культури. При цьому доведено, що пріоритетна орієнтація на захист бізнес-процесів (характерна для переважної більшості сучасних підприємств та організацій) не є виправданою, адже вона тісно пов'язана із соціальною складовою, одне без іншого - неможливе. Керівники, які усвідомили, що технології, виробництво, фінанси, інновації, інвестиції та персонал являються єдиною системою, а останній ще й системоутворюючим елементом, мають великі шанси вийти переможцями, не лише стабілізувавши власне підприємство, але виводячи його на новий рівень розвитку.

\section{Список бібліографічного опису:}

1.Семикіна М.В., Бєляк Т.О. Корпоративна культура та якість людського капіталу: особливості взаємовпливу. Наукові праці Кіровоградського національного технічного університету. Економічні науки. 2015. № 28. С. 68-75.

2.Бугаєвська Ю.В. Поняття корпоративної культури: iï суть і структура. Засоби навчальної та науково-дослідної роботи. 2011. № 36. С. 12-17.

3.Гриценко Н.В. Особливості формування корпоративної культури організації. Вісник економіки транспорту $i$ промисловості. 2017. № 59. С 284-290.

4.Терон I.В. Корпоративна культура в механізмах регулювання соціально-трудових відносин. Глобальні та національні проблеми економіки. 2015. № 6. С. 639-643.

5.Сазонова Т. О., Потапюк І. П., Шаповал В.В. Роль корпоративної культури в сучасній діяльності підприємства. Економічний форум. 2020. №4. С. 131-137.

6.Алексеевский В.С. Динамика ценностей в культуре менеджмента. Экономическая психология: современные проблемы и перспективы развития. Санкт Петербург. 2002. С. 15-17.

7.Кам'янська О.В., Котлярова І.А. Управління інвестиційно-інноваційною діяльністю компанії. Інвестицї̈: практика та досвід. 2014. №3. С. 67-71.

8.Костіна Т. В. Корпоративна культура: іï сутність і формування в Україні Вісник ДонНУЕТ. 2008. № 3. С. 77-84.

9.Овчаренко М. I. Організаційно-економічні засади управління розвитком корпоративної культури промислових підприємств : дис. ... канд. ек. наук : 08.00 .04 / Сум. держ. ун-т. Суми. 2014. 235 с. URL : https://core.ac.uk/download/pdf/324234696.pdf (дата звернення: 03.10.2021).

\section{References:}

1.Cemykina M.V., Bieliak T.O. Korporatyvna kultura ta yakist liudskoho kapitalu: osoblyvosti vzaiemovplyvu. Naukovi pratsi Kirovohradskoho natsionalnoho tekhnichnoho universytetu. Ekonomichni nauky, 2015, no 28, pp. 68-75 [in Ukrainian]. 2.Buhaievska Yu.V. Poniattia korporatyvnoi kultury: yii sut i struktura. Zasoby navchalnoi ta naukovo-doslidnoi roboty. 2011, no 36, pp. 12-17 [in Ukrainian].

3.Hrytsenko N.V. Osoblyvosti formuvannia korporatyvnoi kultury orhanizatsii. Visnyk ekonomiky transportu i promyslovosti. 2017, no 59, pp. 284-290 [in Ukrainian].

4.Teron I.V. Korporatyvna kultura v mekhanizmakh rehuliuvannia sotsialno-trudovykh vidnosyn. Hlobalni ta natsionalni problemy ekonomiky, 2015, no 6, pp. 639-643 [in Ukrainian].

5.Sazonova T. O., Potapiuk I. P., Shapoval V.V. Rol korporatyvnoi kultury v suchasnii diialnosti pidpryiemstva. Ekonomichnyi forum. 2020, no 4, pp. 131-137 [in Ukrainian].

6.Alekseevskij B.C. Dinamika cennostej v kul'ture menedzhmenta. Ekonomicheskaya psihologiya: sovremennye problemy i perspektivy razvitiya. Sankt Peterburg, 2002, pp. 15-17 [in Russian].

7.Kamianska O.V., Kotliarova I.A. Upravlinnia investytsiino-innovatsiinoiu diialnistiu kompanii. Investytsii: praktyka ta dosvid, 2014, no 3, pp. 67-71 [in Ukrainian].

8.Kostina T. V. Korporatyvna kultura: yii sutnist i formuvannia v Ukraini Visnyk DonNUET, 2008, no 3, pp. 77-84 [in Ukrainian].

9.Ovcharenko M. I. Orhanizatsiino-ekonomichni zasady upravlinnia rozvytkom korporatyvnoi kultury promyslovykh pidpryiemstv : dys. ... kand. ek. nauk : 08.00.04 / Sum. derzh. un-t. Sumy, 2014, 235 p. Available at: https://core.ac.uk/download/pdf/324234696.pdf

Дата подання публікації 17.10.2021p. 